\title{
Analysis of Muslim Customer Loyalty Shopping for Fashion in the Traditional Inpres I Market in Kisaran
}

\author{
Isnaini Harahap ${ }^{1}$, Yenni Samri Juliati Nasution ${ }^{2}$, Chairina ${ }^{3}$ \\ ${ }^{1,2,3}$ Faculty of Economics and Islamic Business, Universitas Islam Negeri Sumatera Utara Medan, Indonesia \\ Isnaini.harahap@uinsu.ac.id,yenni.samri@uinsu.ac.id, chairinaguchi@gmail.com
}

\begin{abstract}
Customer loyalty is the customer's commitment to a brand, store, or supplier and is reflected in consistent repeat purchases. This customer loyalty can be influenced by product, price, service, and purchasing decisions. The purpose of this study was to determine the direct and indirect influence between product variables, prices, services, and purchasing decisions on the loyalty of Muslim customers shopping for fashion in the traditional Inpres I Market in Kisaran. Method This study uses a quantitative approach with path analysis and a sample of 100 respondents. The results of this study indicate that product, price, and service variables influence purchasing decisions by $66.6 \%$ and the remaining $33.4 \%$ are influenced by other variables. Whereas product, price, service, and purchasing decision variables affect Muslim customer loyalty in fashion shopping at Traditional Inpres I Market in Kisaran with AA contribution of $70.9 \%$ and the remaining $29.1 \%$ is influenced by other variables. From the results of the significance test of the indirect effect it was found that there was a significant indirect effect of product, price, and service variables on the loyalty of Muslim customers shopping for fashion through purchasing decisions as an intervening variable in the traditional Inpes I Market in the Range with a 95\% confidence level or error rate $5 \%$.
\end{abstract}

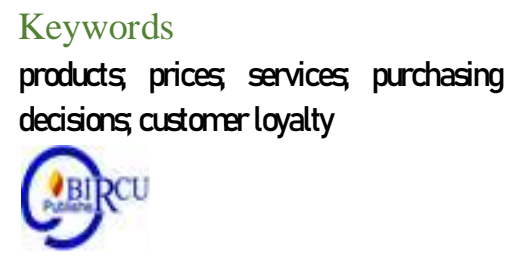

Keywords

products, prices, services, purchasing decisions, customer loyalty

\section{Introduction}

The market is a place where sellers and buyers meet to conduct buying and selling transactions (trades) either directly or indirectly. The market is divided into 2 (two) types, namely traditional and modern markets. (Statistik, 2018) Along with the times, there are many modern markets that offer products that are considered more attractive when compared to traditional markets. One of the products offered is fashion products (clothing). According to Rahanita and Suliswanto, fashion products (clothing) today have switched functions into lifestyle. (Rahanita \& Suliswanto, 2018) This is what makes many modern markets interested in the fashion industry (clothing).

The number of modern markets makes traditional traders worried that one day there will be no more visitors coming to the traditional market. Therefore, traditional markets must be able to improve themselves to be more developed so as not to be abandoned by their customers. To get a lot of consumers, one way to do this is to create customer loyalty. According to Yunita and Waruwo, customer loyalty is a form of customer loyalty to the satisfaction that has been felt at every time shopping so as to foster a sense of loyalty and become a regular customer. (Mella \& Waruwu, 2019) This means that even if there is a modern market that sells fashion products (clothing), if customers are happy with the traditional market then they will still shop in the traditional market. 
In the world of marketing, consumers are assets that must be maintained and maintained their existence in order to remain consistent with the products we produce. One form of commitment that must be given to consumers is by providing good and satisfying services and leading to the creation of customer loyalty (Romdonny and Rosmadi, 2019). According to Swastha and Handoko there are several factors that can influence customer loyalty, namely product, price, satisfaction, experience in terms of service, and emotional bonding. (Gaffar, 2007) Products according to Fandy Tjipno are everything that manufacturers offer to be noticed, sought after, purchased, used or consumed market as a fulfillment of the needs and desires of the market in question. (Firmansyah, Pemasaran: (Dasar dan Konsep), 2019) Products sold in traditional markets and modern markets are almost no different. (Wulandari, Triastity, \& Lamidi, 2016) This means that fashion products (clothing) in traditional markets are not far behind the modern market, even sometimes the products are the same. Fashion products (clothing) in the modern market are usually neatly arranged with a better look, so as to attract the attention of buyers.

Furthermore, the price factor can also affect customer loyalty. Kotler and Amstrong state that the price is a certain amount of money that must be given or paid by the customer to obtain the desired product. (Setiyannigrum, 2015) Prices in traditional markets are formed because of the bargaining process when going to buy fashion products (clothing), so that the trading activities appear and the price is cheaper. Some studies also say similar things, such as research conducted by Mongkaw, et al., which stated that the advantages of traditional markets are that buyers can bid on prices, so that the price that occurs is a mutual agreement between seller and buyer. So, buyers should be good at bargaining prices. (Mongkau, Kawet, \& Sepang, 2017)

According to research conducted by Pramudiana, the price difference between modern market and traditional market is not too far, although when compared to the existing price in modern market the price in traditional market is usually cheaper. (Pramudiana, 2017) In general (according to microeconomic theory), higher prices are less likely to be bought by consumers. However, in some conditions consumers have expectations of price relationship with product quality. Within a certain price range for a product, consumers may have expectations that the price better reflects better quality. (Setiadi, 2013). Consumer behavior is very dynamic and tends to be adaptive, quickly adjust to the demand of the people who always need the public transport. Their demand is complex so that the government should create a good strategy for transport service quality. They need to be managed by the best managers in order to adapt to the users' expectation (Sukesi and Yunus, 2018).

In addition to products and prices, another factor that can affect loyalty is service. Service is a form of certain systems, procedures or methods given to others, with the expectations or desires of customers with a level of perception or opinion. (Mu'ah \& Masram, 2014) The service in the traditional market is quite good because it can give a familiar impression and can make sellers and buyers to know each other until they establish friendship. According to Muftiadi and Maulina, the pattern of service in traditional markets is that buyers or customers are served directly by the seller. In contrast to the modern market whose service pattern is buyers or customers serve themselves in choosing the goods needed. (Muftiadi \& Maulina, 2016)

Purchase decisions can also affect customer loyalty. This is in accordance with research conducted by Susdiarto et al., which states that purchasing decisions have a positive and significant effect on consumer loyalty. (Susdiarto, Priono, \& Swastuti, 2013) According to Schiffman and Kanuk, the purchase decision is an election or an act of two or more alternative options. (Sangadji \& Sopiah, 2013) When the customer feels that the 
product, price and service provided by the merchant is good, then it will encourage the consumer to make a purchasing decision. This is realized in customers after they assess the good products or services of the merchant.

One of the traditional markets engaged in fashion (clothing) that has little concern for the presence of modern market is the traditional Inpres I Market in Kisaran. As a traditional market that sells many products, the location of this market is also quite strategic and located in the middle of the city. The market is also quite clean, has a mosque, parking area, and toilets. However, the market is a little hot. The time span of selling in Pasar Inpres I is also quite long, usually open from 08.15 WIB to 17.45 WIB.

Inpres I market in Kisaran is a market that has been revitalized since 2015 by the government, but this revitalization does not really affect sales. This market consists of 2 floors, but on the 2nd floor there is only one trader. This is because many customers do not want to shop to the 2 nd floor because they are lazy to go up the stairs. So many traders moved to the 1st floor. This market is not only visited by buyers from Kisaran City, but also from outside kisaran city. Types of merchandise are traded variously such as fashion (clothing), accessories, beauty products, bags, shoes, headscarves, and so forth. The most widely offered products in the traditional Inpres I Market This range is fashion products.

Based on data obtained from the Office of Cooperatives and Trade, the number of traders inPres Market I in 2017 and 2018 amounted to 403 people, while in 2019 the number of traders dropped dramatically to 240 people. According to two people who have been selling for more than 25 years in the traditional Inpres I Market, they say that the decrease in the number of traders is due to the decrease in the number of market visitors (the lack of buyers). Even though the promotion through social media has also been done. Many customers are switching from traditional markets to modern markets in The City of Range. This caused many traders to choose not to trade anymore, so many stalls were empty, especially second floor kiosks.

However, although the number of traders dropped dramatically, many traders also survived. This is because sales in the market during Sundays and other big days such as Islamic holidays can still be expected. In addition, traders feel that there are still many customers who are still loyal to them, even though there are many modern markets emerging. Customer loyalty is what makes traditional markets can survive and be able to compete with modern markets.

From a short interview with two Muslim customers who bought fashion (clothing) at Pasar Inpres I Kisaran, they said they prefer to shop in traditional markets compared to modern markets. This is because the traditional market of its products is very diverse and the price is cheaper. In addition, they feel welcomed when they come to the traditional I presidential market, each trader offers their goods to them, so that they feel served.

\section{Review of Literatures}

\subsection{Market}

The market is a tempet of meeting sellers and buyers in an area, place, region, area, where there are bidding activities that meet each other and form prices. The market is generally classified into 2 (two) traditional markets (prices are formed from the bargaining process) and modern markets (the price is set). (Fuad, H, Nurlela, Sugiarto, \& Y.E.F, 2006) Characteristic differences between traditional and modern markets can be seen from several aspects, namely history, physical, ownership or institutional, capital, consumers, payment methods, land status, financing, development, incoming traders, participation, and networks. (Fajriawati, 2017) 


\subsection{Customer Loyalty}

Kotler in Kusumadewi (2019) suggested that: "Customer perceived value is the difference between the prospective customer's evaluation of all benefits and all costs of an offering and perceived alternatives. Total customer value is the perceived monetary value of the bundle of economic, functional and psychological benefit customer expect from a given market offering product. Total customer cost is the bundle of cost customer expect to incur in evaluating, obtaining, using and disposing of the given market offering.

Customer loyalty is a purchase that customers make regularly, continuously and over and over again in the same place. (Suryati, 2015) According to Swastha and Handoko there are several factors that can influence customer loyalty, namely product, price, satisfaction, experience in terms of service, and emotional bonding. (Gaffar, 2007) The benefits of customer loyalty can increase the purchase of goods or services, can lower costs, can improve positive word of mouth communication, and can reduce employee staff turnover. (Mu'ah \& Masram, 2014) According to Griffin, the dimension of customer loyalty is to repurchage regularly, buy outside the product line, refer or recommend products to others, and show immunity to the attractiveness of competitors. (Griffin, 2003)

In Islam, loyalty is very important because loyalty is one of the good signs of whether or not a Muslim faith. In Arabic loyalty is called al-wala' which means close. Whereas in Islamic terms loyalty is the closeness between fellow Muslims in terms of love and mutual assistance (helping). (Taufiq, 2006) Customer loyalty in Islamic view can be done by doing transactions with people of faith (Muslims). It takes precedence over doing tyransaksi with musrik people.

\subsection{Product}

Products are something that can be offered in the market to be noticed, owned, used or consumed in order to meet the needs and desires. Products can be in the form of goods or services. (Firmansyah, Pemasaran: (Dasar dan Konsep), 2019) According to Fandy Tjipno, there are 5 (five) levels of products namely main or core products, generic products, hope products, complementary products, and potential products. According to Mullins, Orville, and Boyd the product dimensions are divided into performance, durability, conformity to specifications, features, aesthetics and quality impressions. (Firmansyah, Pemasaran Produk dan Merek (Planning dan Strategy), 2019)

\subsection{Price}

According to Kotler and Amstrong, the price is a certain amount of money asked to get a product or service. (Setiyannigrum, 2015) The factors that can affect the price are non-cost factors such as economic condition, demand elasticity, market type, demand and supply, competitor reaction, government influence, public impression, non-profit, and corporate social responsibility and cost factor. According to Kotler and Amstrong, the price dimension is divided into 4 (four), namely price affordability, price competitiveness, price conformity with the quality and benefits produced. (Kotler \& Amstrong, 2012) In Islam, the prevailing price in the market should be a fair price. That is, the price set is not too expensive and not too cheap until it suffers losses. (Harahap, Nasution, \& Marliyah, 2014)

\subsection{Service}

According to Kotler, service is an activity or benefit offered by one party to another that is fundamentally intangible and does not result in any ownership. Activities or benefits offered by one party to another party that are inherently intangible and do not result in any 
ownership. According to A. Pasurama, the service dimension is 5 (five) and is better known as the servqual dimension, namely physical evidence, reliability, responsiveness, assurance, and empathy. In Islam, service can be reflected by being meek and not rude to others (customers). (Mu'ah \& Masram, 2014)

\subsection{Purchasing Decision}

According to Schiffman and Kanuk, the purchase decision is an act or selection of two alternative options or more. According to Kotler the purchase decision can be taken by product, price, service, promotion, and place (distribution channel). The purchasing decision process begins with the introduction of problems, information search, alternative evaluation, purchase decisions, and ends with post-purchase evaluation. According to Kotler and Keller the dimensions of purchasing decisions are the need for products, buying confidence, and other people's attitudes towards the product. In Islam, purchasing decisions must be based on good goods (halal) should not be excessive, and prioritize priority. (Sangadji \& Sopiah, 2013)

\section{Research Methods}

This research was conducted using the help of SPSS program version 20.0. The data sources in this study are primary data and secondary data. The population in this study amounted to 100 respondents with non probability sampling techniques (based on coincidence or convenience). This sample technique is done by visiting respondents and selecting prospective respondents who are encountered by chance. However, prospective respondents must also have certain characteristics, namely respondents who are Muslim and make purchases of goods bataupun repeat products at the traditional Inpres I Market in Kisaran. Data collection is done by observation, interview, questionnaire, and documentation study (library). This research uses quantitative approach with path analysis. The path diagram is as follows:

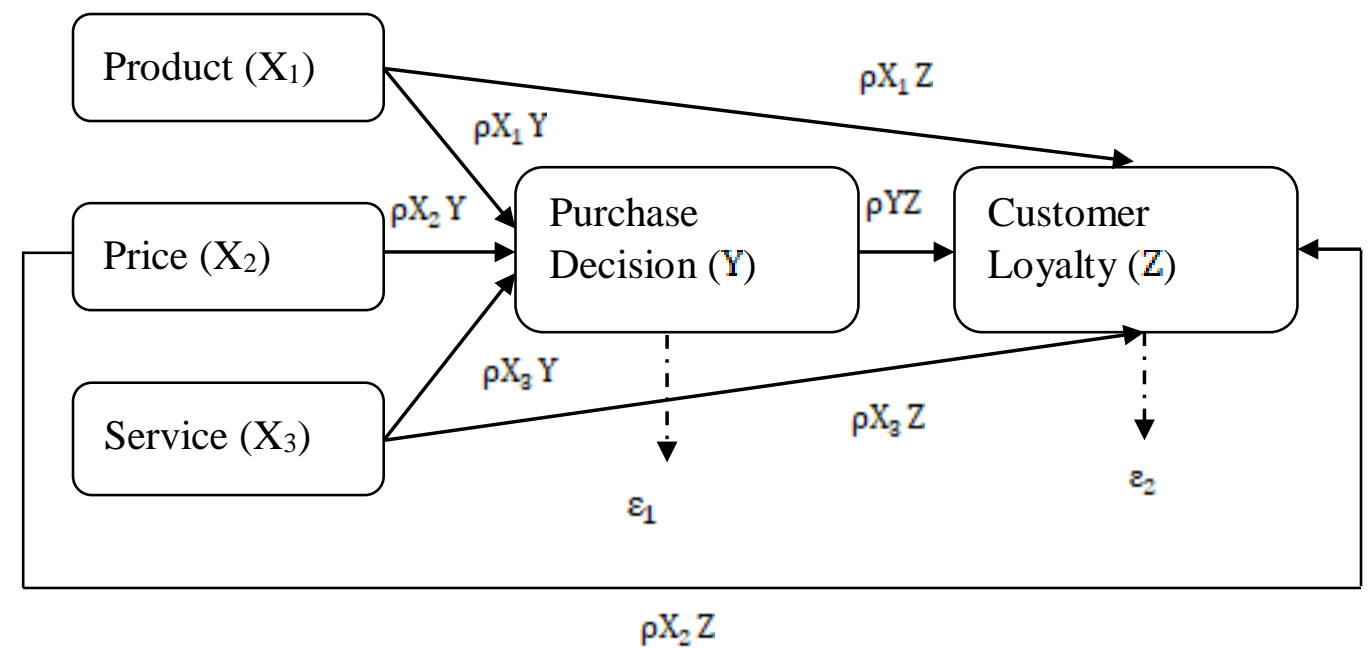

Figure 1. Path Diagram

Structural Model I $\rightarrow \mathrm{Y}=\left[\rho X \rrbracket \_1 \mathrm{Y}+\rho \mathrm{X} \_2 \mathrm{Y}+\rho \mathrm{X} \_3 \mathrm{Y}\left[+\varepsilon \rrbracket \_1\right.\right.$

Structural Model II $\rightarrow Z=[\rho X) \_1 Z+\rho X \_2 Z+\rho X \_3 Z+\rho Y Z+\varepsilon \_2$ 


\section{Results and Discussion}

\subsection{Results}

Based on the test results of structural hypothesis model I and structural model II, it can be made a summary table of track analysis as follows:

Table 1. Path Analysis Summary

\begin{tabular}{|c|c|c|c|c|c|c|c|}
\hline $\begin{array}{c}\text { Influence } \\
\text { Between } \\
\text { Variables }\end{array}$ & $\begin{array}{c}\text { Path } \\
\text { Coefficient } \\
\text { (pij) }\end{array}$ & $\begin{array}{c}\text { Standard } \\
\text { Error } \\
\text { (Sbi) } \\
\end{array}$ & $\boldsymbol{t}_{\text {hitung }}$ & $F_{\text {hitung }}$ & $\rho_{\text {value }}$ & Conclusion & $\mathbf{R}^{2}$ \\
\hline \multicolumn{8}{|c|}{ Structural Equations $I\left(X_{1}, X_{2}, X_{3}\right.$ to $\left.Y\right)$} \\
\hline $\begin{array}{c}\mathrm{X}_{1} \text { against } \mathrm{Y} \\
\mathrm{pX}_{1} \mathrm{Y}\end{array}$ & 0,338 & 0,086 & 3,915 & \multirow{3}{*}{63,867} & 0,000 & Significant & \multirow[t]{3}{*}{0,666} \\
\hline $\begin{array}{c}\mathrm{X}_{2} \text { against } \mathrm{Y} \\
\mathrm{pX}_{2} \mathrm{Y}\end{array}$ & 0,278 & 0,089 & 3,141 & & 0,002 & Significant & \\
\hline $\begin{array}{c}\mathrm{X}_{3} \text { against } \mathrm{Y} \\
\mathrm{\rho X}_{3} \mathrm{Y}\end{array}$ & 0,322 & 0,086 & 3,730 & & 0,000 & Significant & \\
\hline \multicolumn{8}{|c|}{ Structural Equations II $\left(\left(\mathbf{X}_{1}, \mathbf{X}_{2}, \mathbf{X}_{3}, \mathbf{Y}\right.\right.$ to $\left.\mathbf{Z}\right)$} \\
\hline $\begin{array}{c}\mathrm{X}_{1} \text { against } \mathrm{Z} \\
\rho \mathrm{X}_{1} \mathrm{Z}\end{array}$ & 0,301 & 0,101 & 2,977 & \multirow{4}{*}{57,894} & 0,004 & Significant & \multirow{4}{*}{0,709} \\
\hline $\begin{array}{c}\mathrm{X}_{2} \text { against } \mathrm{Z} \\
\mathrm{\rho X}_{2} \mathrm{Z}\end{array}$ & 0,252 & 0,01 & 2,489 & & 0,015 & Significant & \\
\hline $\begin{array}{c}\mathrm{X}_{3} \text { against } \mathrm{Z} \\
\mathrm{\rho X}_{3} \mathrm{Z}\end{array}$ & 0,226 & 0,100 & 2,251 & & 0,027 & Significant & \\
\hline $\begin{array}{c}\text { Y against } Z \\
\text { PYZ }\end{array}$ & 0,347 & 0,111 & 3,129 & & 0,042 & Significant & \\
\hline
\end{tabular}

\section{a. Determination Test $\left(\mathbf{R}^{2}\right)$}

Based on the table above, for structural model I, the percentage of influence of products, prices and services on fashion purchasing decisions at the Traditional Presidential Market I in Kisaran is 0.666 or $66.6 \%$, and the remaining $33.4 \%$ is influenced by other variables. Whereas for structural model II, the percentage of influence of products, prices, services, and purchase decisions on Muslim customer loyalty shopping for fashion at the Traditional Presidential Market I in Kisaran is 0.709 or $70.9 \%$, and the remaining $33.4 \%$ is influenced by other variables.

\section{b. ANOVA Test (F-Test)}

For structural model I in the ANOVA test $(\mathrm{F}-\mathrm{Test})$ it was found that the value $\mathrm{F}_{\text {count }}=$ $63.827>\mathrm{F}_{\text {table }}=2.70$ with a significance level or a probability of $0.000<0.05$ and $\mathrm{H}_{0}$ is rejected. This means that there is a joint influence (simultaneously) between the independent variables (product, price, and service) and the intervening variable (purchase decision). As for the structural model $\mathrm{I}$, it is found that the value of $\mathrm{F}_{\text {count }}=57.894>\mathrm{F}_{\text {table }}$ $=2.47$ with a significance level or a probability of $0.000<0.05$ and $\mathrm{H}_{0}$ is rejected. This means that there is an influence together (simultaneously) between independent variables (products, prices, and services) and intervening variables (purchasing decisions). 


\section{c. Partial Test (T-Test)}

From the path analysis summary table on the structural model I it can be seen that the product, price, and service partially have a positive and significant effect on the purchasing decision. The product contribution $=33.8 \%$, price $=27.8 \%$, and service $=32.2 \%$. While in structural model II it can be seen that $t_{\text {count }}>t_{\text {table }}(2,977>1,985)$ and sig. < level of significant $0.004<0.05$, meaning that the product, price, service, and purchasing decisions partially have a positive and significant effect on customer loyalty. Product contribution $=$ $30.1 \%$, price $=25.2 \%$, service $=22.6 \%$, and purchase decision $=34.7 \%$.

\section{d. Direct Influence Results}

The results of direct influence in this research are as follows:

Table 2. Direct Influence Results

\begin{tabular}{|c|c|c|c|c|}
\hline Hypothesis & Description & Significant & Conclusion & \multirow{2}{*}{$\mathbf{R}^{\mathbf{2}}$} \\
\hline 1 & $\mathrm{H}_{0}$ rejected $\mathrm{H}_{a}$ accepted & $0,000<0,05$ & Significant & \\
\cline { 1 - 4 } 2 & $\mathrm{H}_{0}$ rejected $\mathrm{H}_{a}$ accepted & $0,002<0,05$ & Significant & \multirow{2}{*}{0,666} \\
\hline 3 & $\mathrm{H}_{0}$ rejected $\mathrm{H}_{a}$ accepted & $0,000<0,05$ & Significant & \\
\cline { 1 - 4 } & $\mathrm{H}_{0}$ rejected $\mathrm{H}_{a}$ accepted & $0,004<0,05$ & Significant & \\
\cline { 1 - 4 } & $\mathrm{H}_{0}$ rejected $\mathrm{H}_{a}$ accepted & $0,015<0,05$ & Significant & \multirow{2}{*}{0,709} \\
\cline { 1 - 4 } & $\mathrm{H}_{0}$ rejected $\mathrm{H}_{a}$ accepted & $0,027<0,05$ & Significant & \\
\hline 7 & $\mathrm{H}_{0}$ rejected $\mathrm{H}_{a}$ accepted & $0,042<0,05$ & Significant & \\
\hline
\end{tabular}

\section{e. Test the Significance of Indirect Influence}

The test results of indirect influence significance are as follows:

Table 3. Test Results of Indirect Influence Significance

\begin{tabular}{|c|c|c|c|}
\hline indirect effect & $\boldsymbol{z}_{\text {litung }}$ & $\boldsymbol{t}_{\text {tabel }}$ & Conclusion \\
\hline $\mathrm{X}_{1}$ against $\mathrm{Z}$ through $\mathrm{Y}$ & 2,438 & 1,985 & Significant \\
\hline $\mathrm{X}_{2}$ against $\mathrm{Z}$ through $\mathrm{Y}$ & 2,182 & 1,985 & Significant \\
\hline $\mathrm{X}_{3}$ against $\mathrm{Z}$ through $\mathrm{Y}$ & 2,383 & 1,985 & Significant \\
\hline
\end{tabular}

From the calculations and tables above, it can be concluded that there is a significant or real indirect influence of product variables, prices, and service to customer loyalty (Z) muslim fashion shopping through purchasing decisions (Y) as intervening variables in the traditional Inpres I Market in Kisaran with a confidence level of $95 \%$ or a 5\% error rate.

\subsection{Discussion}

\section{a. Product Influence on Purchasing Decisions}

The results of this study showed that product variables $\left(\mathrm{X}_{1}\right)$ ) affect purchasing decisions (Y). This means that if the fashion products offered by the traditional Inpres I Market in Kisaran of good quality and varied (diverse), it will further attract consumers to make purchasing decisions in that market. Theoretically according to Kotler, consumers have an interest in making purchasing decisions on a product offered by the market. However, this interest is influenced by the supporting factors of the product itself, such as product quality, product variation or model, product comfort and so on. Therefore, the products offered by the market should be good. If the product is good, it will automatically affect the consumer's decision to make a purchase decision. 


\section{b. Price Effect on Purchasing Decisions}

The results of this study showed that the price $\left(\mathrm{X}_{2}\right)$ has a positive effect on the purchasing decision $(\mathrm{Y})$. That is, if the price offered by the traditional Inpres I Market in Kisaran increases, then the purchasing decision will also increase. Theoretically Price is one of the determining factors of Muslim consumers in making purchasing decisions. According to microeconomic theory, higher prices are less likely to be bought by consumers. However, in some conditions consumers have expectations of price relationship with product quality. Within a certain price range for a product, consumers may have an expectation that the price better reflects the better quality The price influence on this study is smallest when compared to the influence on other variables examined in this study. However, it still contributes significantly to the decision to purchase fashion at the traditional Inpres I Market in Kisaran. The price is formed from an agreement between the seller and the buyer as has been done by Pasar Inpres I in Kisaran through the bargaining process so that a fair price is formed in accordance with Islamic law.

\section{c. Effect of Service on Purchasing Decisions}

The results of this study indicate that service $\left(\mathrm{X}_{3}\right)$ has an effect on purchasing decisions (Y). It has a positive effect, meaning that if the services provided by the traditional Inpres I Market in Kisaran are good, then purchasing decisions will also increase. Theoretically, service is a certain form of system, procedure or method given to others, with the expectations or desires of customers with their level of perception. It means that in terms of service, the market must adjust to the wishes of its consumers so that consumers feel happy and interested in making purchases at the place.

\section{d. Product Influence on Customer Loyalty}

The results of this study indicate that the product $\left(\mathrm{X}_{1}\right)$ has an effect on purchasing decisions (Y). A product with a positive effect means that the better the fashion products offered by the traditional Inpres I Market in Kisaran, the more consumers will make purchasing decisions in that market. Theoretically the findings of this study suggest that the product affects customer loyalty. According to Mullins, Orville, Larreche, and Boyd if the company wants to maintain its competitive advantage in the market, the company must understand what aspects of dimensions are used by consumers to distinguish the products sold by those markets from the products (modern markets). The product must be of quality and have a long life (durable). In addition, the market should pay close attention to the products offered, whether there are defects in them or not. If the dimensions of this product are good, it will make consumers to be loyal to the company.

\section{e. Effect of Price on Customer Loyalty}

The results of this study indicate that price $\left(\mathrm{X}_{2}\right)$ towards customer loyalty $(\mathrm{Y})$. It has a positive effect, meaning that if the price offered by the market varies increases, customer loyalty will also increase. Theoretically, the findings of this study indicate that price can provide an incentive to make consumers loyal as suggested by Kotler. The price of fashion products set in Pasar Inpres I is enough in accordance with the quality and benefits felt. The price offered by the market is quite high, but the price can still be offered by the buyer. Therefore, customers must be good at bargaining the price of goods offered by traders. So that customers can get a fair price in accordance with the agreement between the seller and the buyer in accordance with the teachings of Islam. 


\section{f. The Effect of Service on Customer Loyalty}

The results of this study showed that service $\left(\mathrm{X}_{3}\right)$ affect customer loyalty $(\mathrm{Z})$. That is, if the service performed by Pasar Inpres I in Kisaran is in accordance with or close to the customer's wishes, then customer loyalty will also increase. Theoretically, according to Kotler, service is an activity or benefit offered by one party to another that is inherently intangible and does not result in any ownership. This service is usually more felt and usually in the form of facilities, convenience or attitude of employees of the company or market. Good service will make customers feel comfortable, so that customers can make repeated purchases in that market.

\section{g. The Effect of Purchasing Decisions on Customer Loyalty}

The results of this study show that purchasing decisions (Y) affect customer loyalty (Z). That is, if the purchasing decision at the traditional Inpres I Market in Kisaran increases, then the loyalty of Muslim customers will also increase. Theoretically customer loyalty is a purchase that customers make regularly and repeatedly. Whereas according to Schiffman and Kanuk the purchase decision is an election or an act of two or more alternative options. One of the objectives of a business is to create customers to buy again. Customer purchasing decisions can be the basis for the realization of loyal customers.

\section{h. The Influence of Products on Customer Loyalty Through Purchasing Decisions}

The results of this study showed that the product $\left(\mathrm{X}_{1}\right)$ has a significant effect on customer loyalty $(\mathrm{Z})$ muslim fashion shopping at the Inpres I Market in Kisaran through purchasing decisions (Y). Theoretically, loyalty can be interpreted as being loyal and repurchasing. This loyalty starts from the products offered by the market, then purchased by consumers. Products are usually judged by consumers of quality so that they can be trusted and provide comfort. In addition, consumers also like products that are diverse or varied. If the products offered by the market are good (durable, good reputation, not defective, diverse or varied), then it will make consumers loyal to the market.

\section{i. The Influence of Price on Customer Loyalty through Purchasing Decisions}

The results of this study showed that the price $\left(\mathrm{X}_{2}\right)$ has a significant effect on customer loyalty $(Z)$ muslim fashion shopping at the Inpres I Traditional Market in Kisaran through purchasing decisions (Y). Theoretically, the findings of this study suggest that price can affect customer loyalty through purchasing decisions. However, consumers must buy an item first can only be loyal to the market or the company. According to Kotler consumer behavior in making purchasing decisions can also be influenced by price. The more varied and affordable the price, the more interested consumers will be to make purchasing decisions.

\section{j. The Effect of Service on Customer Loyalty Through Purchasing Decisions}

The results of this study showed that service $\left(\mathrm{X}_{3}\right)$ has a significant effect on customer loyalty $(\mathrm{Z})$ muslim fashion shopping at the Inpres I traditional Market in Kisaran through purchasing decisions (Y). Theoretically according to the dictionary of service business is an economic activity carried out to meet the needs of a business or personal. Service is usually caused by compassion, love, a belief to help each other, and the belief that one form of charity is to do good to others. This is in accordance with Islamic law which says to be meek towards others. 


\section{Conclusion}

From the results of the research, it can be concluded that products, prices, services, and purchasing decisions have a significant effect on customer loyalty both simultaneously and partially. Similarly, the influence of products, prices and services that have a significant influence on purchasing decisions. This is because customers feel that the products produced by the traditional Inpres I market in Kisaran are good and diverse with varying prices but quite high and negotiable. The service in this market is also quite good in terms of facilities and in terms of the behavior of traders in serving. In addition products, services, prices also affect customer loyalty through intervening variables.

\section{References}

A. Setiyannigrum, "Prinsip-prinsip Pemasaran," Yogyakarta, Andi Offset, 2015, p. 128.

B. P. Statistik, "Profil Pasar Tradisional, Pusat Perbelanjaan dan Toko Modern Tahun 2018," Jakarta, Badan Pusat Statistik, 2018, p. 7.

B. Susdiarto, A. E. Priono and E. Swastuti, "Pengaruh Produk dan Harga Terhadap Loyalitas Konsumen Dengan Keputusan Pembelian Sebagai Variabel Mediasi Pada PT Pertani (Persero) Cabang Pekalongan," Jurnal Ilmiah Dinamika Ekonomi dan Bisnis, vol. 1, no. 2, p. 9, 2013.

E. M. Sangadji and S. , "Perilaku Konsumen: Pendekatan Praktis Disertai Himpunan Jurnal Penelitian," Yogyakarta:, Andi Offset, 2013, p. 107.

Fajriawati, "Analisis Pengaruh Persaingan Usaha Pasar Tradisional Terhadap Pasar Modern Peraturan Daerah Kota Medan," Jurnal Varia Justicia, vol. 13, no. 2, p. 109, 2017.

G. Mongkau, L. Kawet and J. Sepang, "Pengaruh Kualitas Produk, Harga, Dan Tempat Terhadap Kepuasan Konsumen Pada Pasar Tradisional Remboken (Studi Kasus Pada Masyarakat Desa Sinuian Kec. Remboken)," Jurnal Riset Ekonomi, Manajemen, Bisnis dan Akuntansi., vol. 5 , no. 2, p. 2470, 2017.

I. Harahap, Y. S. J. Nasution and M., Hadis-Hadis Ekonomi, Medan: Wal Asrhri Publishing., 2014.

I. D. Pramudiana, "Perubahan Perilaku Komsumtif Masyarakat Dari Pasar Tradisional ke Pasar Modern," Jurnal Agama dan Perubahan Sosial, vol. 1, no. 1, p. 36, 2017.

J. Griffin, "Customer Loyalty: Menumbuhkan dan Mempertahankan Kesetiaan Pelanggan," Jakarta, Erlangga, 2003, p. 133.

Kusumadewi, R. (2019). The Role of Marketing and Individual Environment Association in Elevating the Customer Value. Budapest International Research and Critics Institute-Journal (BIRCI-Journal). P. 451-460.

L. Suryati, "Manajeman Pemasaran: Suatu Strategi Dalam Meningkatkan Loyalitas Pelanggan," Yogyakarta, Deepublis, 2015, p. 93.

M. and M. , "Loyalitas Pelanggan: Tinjauan Aspek Kualitas Pelayanan dan Biaya Peralihan," Yogyakarta, Zifatama Publisher, 2014, p. 57.

M. Fuad, C. H, N. S. and P. Y.E.F, "Pengantar Bisnis," Jakarta, Gramedia Pustaka Utama, 2006, p. 120.

M. and M. , "Loyalitas Pelanggan: Tinjauan Aspek Kualitas Pelayanan dan Biaya Peralihan," Yogyakarta, Zifatama Publishe, 2014, p. 120.

M. A. Firmansyah, "Pemasaran: (Dasar dan Konsep)," Surabaya, Qiara Media, 2019, p. 168. 
M. I. Taufiq, "Panduan Lengkap dan Praktis Psikologi Islam, Sari Narulita,," Jakarta, Gema Insani Press, 2006, p. 699.

M. A. Firmansyah, "Pemasaran Produk dan Merek (Planning dan Strategy)," Surabaya, Qiara Media, 2019, p. 9.

M. Muflih, "Prilaku Konsumen Dalam Perspektif Ilmu Ekonomi Islam," Jakarta, Raja Grafindo Persada, 2006.

N. J. Setiadi, in Prilaku Konsumen: Perspektif Kontemporer Pada Motif, Tujuan, dan Keinginan Konsumen, Jakarta, Kencana, 2013, p. 107.R. and M. S. W. Suliswanto, "Analisis Perbedaan Harga Jual Pakaian Wanita Antara Pasar Tradisional dan Pasar Modern di Kota Mojokerto," Jurnal Ilmu Ekonomi, vol. 2, no. 3, p. 428, 2018.

P. Kotler and G. Amstrong, "Prinsip-Prinsip Pemasaran. Terj. Bob Sabran," Jakarta, Erlangga., 2012, p. 52.Y. Mella and K. Waruwu, "Dampak Keberadaan Pasar Modern Terhadap Loyalitas Konsumen Pada Pasar Tradisional (Studi Kasus Pasar Kampung Lalang Kecamatan Medan Sunggal)," Jurnal Ilmiah Maksitek, vol. 4, no. 3, p. 56, 2019.

R. Wulandari, R. Triastity and L. , "Analisis Pengaruh Citra Pasar Tradisional Terhadap Loyalitas Konsumen Dengan Kepuansan Konsumen Sebagai Variabel Mediasi (Survei Pada Konsumen Pasar Gede Solo)," Jurnal Ekonomi dan Kewirausahan, vol. 16, 2016.

R. A. Muftiadi and E. Maulina, "The Bussiness Dynamic Traditional Market Place: Demand Preference Approach," Jurnal AdBispreneur, vol. 1, no. 2, p. 114, 2016.

Romdonny, J., and Rosmadi, M.L.N. (2019). Factors Affecting Customer Loyalty in Products. Budapest International Research and Critics Institute-Journal (BIRCIJournal). P. 337-343.

Sukesi and Yunus, E. (2018). Service Quality in Public Transport Services of the Provicial Intercity. Transportation (AKDP) in East Java Indonesia. Budapest International Research and Critics Institute-Journal (BIRCI-Journal). P. 161-169.

Supriono, "Akuntansi Manajemen: Proses Pengendalian Manajemen," Yogyakarta, STIE YKPN, 2001.

S. and H. , "Metode Riset Kuantitatif: Teori dan Aplikasi Pada Penelitian Bidang Manajemen dan Ekonomi Islam," Jakarta, Kencana, 2015.

V. Gaffar, "Manajemen Bisnis," Bandung, Alfabeta, 2007, p. 45 